\title{
Profil Klinis dan Pemeriksaan Penunjang pada Penyakit Kawasaki
}

\author{
Sita Ariyani, Najib Advani, Dwi Putro Widodo \\ Departemen Ilmu Kesehatan Anak Fakultas Kedokteran Universitas Indonesia-Rumah Sakit Cipto \\ Mangunkusumo
}

Latar belakang. Penyakit Kawasaki (PK) merupakan vaskulitis akut sistemik yang mempunyai predileksi pada arteri koroner terutama bayi dan anak balita. Kejadian 20\%-40\% kasus PK yang tidak diobati akan mengalami kelainan arteri koroner. Masalah PK di Indonesia saat ini masih banyak underdiagnosis dan terlambat didiagnosis, serta beberapa kasus overdiagnosis.

Tujuan. Mengetahui profil klinis dan pemeriksaan penunjang PK pada anak di Indonesia.

Metode: Penelitian deskriptif potong lintang. Data diperoleh dari rekam medis pasien berusia 0-18 tahun dengan diagnosis PK selama satu tahun di tiga rumah sakit di Jakarta dan Tangerang.

Hasil. Didapatkan 66 subjek yang sesuai dengan diagnosis PK, 77\% berusia balita dengan usia tersering 1-2 tahun. Anak lelaki dan perempuan berbanding 2:1. Seluruh subjek mengalami demam dengan gambaran klinis paling sering adalah perubahan bibir dan rongga mulut, seperti eritema, bibir pecah-pecah, lidah stroberi, dan eritema difus mukosa orofaring (100\%); ruam polimorfik (89\%); dan injeksi konjungtiva tanpa eksudat (88\%). Gambaran klinis paling jarang adalah limfadenopati servikal unilateral (53\%). Anemia dan leukositosis sering terjadi pada fase akut, sedangkan trombositosis mulai terjadi pada minggu kedua. Peningkatan LED dan CRP terjadi pada fase akut, tetapi pada 15\% subjek peningkatan LED tidak disertai oleh peningkatan CRP atau sebaliknya. Hipoalbuminemia terjadi pada $70 \%$ subjek. Gambaran infiltrat pada foto toraks didapatkan $71 \%$ subjek. Aneurisma arteri koroner pada ekokardiografi saat awal diagnosis didapatkan 30\% subjek. Sebagian besar merupakan aneurisma kecil, 3\% aneurisma sedang, dan $1 \%$ aneurisma raksasa.

Kesimpulan. Gambaran klinis sering selain demam adalah perubahan bibir dan rongga mulut, ruam polimorfik, dan injeksi konjungtiva tanpa eksudat, sedangkan yang jarang adalah limfadenopati servikal unilateral. Pemeriksaan LED dan CRP sebaiknya dilakukan bersamaan untuk mendukung diagnosis. Hipoalbuminemia dan gambaran infiltrat pada foto toraks mungkin dapat dipertimbangkan sebagai alat bantu diagnosis PK, namun masih membutuhkan penelitian lebih lanjut untuk membuktikannya.

Sari Pediatri 2014;15(6):385-93.

Kata kunci: penyakit Kawasaki, anak, Indonesia

\footnotetext{
Alamat korespondensi:

Dr. Najib Advani, SpA(K). Departemen Ilmu Kesehatan Anak Fakultas Kedokteran Universitas Indonesia-Rumah Sakit Cipto Mangunkusumo. Jl Diponegoro no. 71, Jakarta. Telp. ()21) 3155742,3925901. E-mail: advanin@idai.or.id,sitariyani@yahoo.com
}

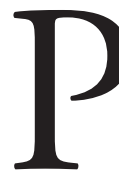
enyakit Kawasaki (PK) merupakan vaskulitis akut sistemik yang belum diketahui penyebabnya dan mempunyai predileksi pada arteri koroner terutama bayi dan anak 
balita. ${ }^{1-6}$ Penyakit Kawasaki merupakan penyakit jantung didapat pada anak yang paling sering ditemukan di negara maju, seperti Amerika Serikat, Inggris, dan Jepang, sedangkan di negara berkembang penyakit jantung reumatik masih menduduki tempat teratas. ${ }^{1,2,4,5,7}$

Penyakit Kawasaki telah dilaporkan terjadi di seluruh penjuru dunia dan dapat mengenai semua ras dengan insiden yang bervariasi. ${ }^{8,9}$ Insiden tertinggi berada di Jepang dengan angka kejadian mencapai 218 per 100.000 anak balita pada tahun $2007-2008 .^{10}$ Berdasarkan angka kejadian PK di beberapa negara, Advani $\mathrm{dkk}^{11}$ memperkirakan terdapat sekitar 5000 kasus baru setiap tahun di Indonesia, tetapi kasus yang dapat didiagnosis tercatat kurang dari 200 kasus per tahun (4\%) sehingga masih ada sekitar 96\% kasus PK di Indonesia yang belum terdeteksi. Penyakit Kawasaki dianggap masih jarang di Indonesia dan belum diketahui secara luas, baik di kalangan tenaga medis maupun masyarakat. ${ }^{12}$ Masalah utama PK di Indonesia saat ini adalah masih banyak kasus yang tidak terdiagnosis (underdiagnosis) dan terlambat didiagnosis. Beberapa kasus yang tidak memenuhi kriteria diagnosis PK, tetapi didiagnosis dan diterapi sebagai PK (overdiagnosis) juga mulai ditemukan. Kasus yang underdiagnosis, terlambat, maupun overdiagnosis harus dihindari karena akan merugikan pasien. ${ }^{13}$

Didapatkan 20\%-40\% kasus PK yang tidak diobati akan mengalami kelainan arteri koroner seperti aneurisma, trombosis, stenosis koroner, dan infark miokard yang dapat berakhir pada kematian, sedangkan dengan pengobatan insidennya turun menjadi 3\%-5\%., . $^{314}$ Gejala sisa akibat PK dapat mengganggu tumbuh kembang anak akibat kecacatan pada jantung. ${ }^{5}$ Anak dengan PK yang mengalami komplikasi koroner yang berat memerlukan penanganan jangka panjang, seperti tindakan intervensi jantung, operasi bedah pintas koroner, bahkan transplantasi jantung. Kondisi tersebut memberikan dampak yang sangat besar bagi pasien, orangtua, keluarga, dan lingkungannya. ${ }^{14}$ Penyakit Kawasaki juga merupakan faktor risiko potensial terjadinya penyakit jantung iskemik dan kematian mendadak pada usia dewasa muda. ${ }^{15}$ Diagnosis dini serta pengobatan yang cepat dan tepat dapat mengurangi angka kejadian aneurisma koroner secara bermakna sehingga dapat menurunkan morbiditas pasien baik pada masa anak maupun masa depannya. ${ }^{14,15}$

Diagnosis PK ditegakkan berdasarkan kriteria klinis, didukung oleh data laboratorium, serta pemeriksaan penunjang lain terutama ekokardiografi. ${ }^{1-8}$ Diagnosis PK komplet ditegakkan apabila pasien mengalami demam $\geq 5$ hari, ditambah $\geq 4$ kriteria klinis klasik, dan disingkirkannya penyakit lain yang mempunyai kemiripan gejala. Kriteria klinis klasik tersebut yaitu injeksi konjungtiva bilateral tanpa eksudat; perubahan pada bibir dan rongga mulut (eritema, bibir pecah-pecah, lidah stroberi, dan eritema difus mukosa orofaring); ruam polimorfik; limfadenopati servikal unilateral (diameter $>1,5$ $\mathrm{cm}$ ); dan perubahan pada ekstremitas (edema dan eritema telapak tangan dan kaki pada fase akut serta deskuamasi periungual jari-jari tangan dan kaki pada fase subakut/konvalesens). ${ }^{1-3}$ Diagnosis PK inkomplet ditegakkan apabila pasien mengalami demam $\geq 5$ hari, ditambah $<4$ kriteria klinis klasik lainnya, tetapi ditemukan abnormalitas arteri koroner pada ekokardiografi atau angiografi., ${ }^{2,6}$

Gejala klinis klasik PK dapat muncul pada saat yang tidak bersamaan dan dapat mirip dengan penyakit lain sehingga kadang diperlukan waktu untuk mengamati gejala yang timbul sebelum menegakkan diagnosis. ${ }^{1}$ Kesulitan untuk menegakkan diagnosis muncul apabila pasien datang pada minggu kedua perjalanan penyakit, sedangkan gejala klinis klasik mungkin saja sudah menghilang pada waktu tersebut atau mungkin tidak muncul sama sekali. ${ }^{7}$ Selain itu, kesulitan diagnosis juga timbul karena tidak adanya alat bantu yang dapat memastikan diagnosis PK. ${ }^{13}$ Hingga saat ini, belum ada pemeriksaan penunjang yang bersifat diagnostik untuk PK, tetapi beberapa temuan hasil laboratorium dapat membantu mendukung diagnosis terutama pada kasus PK inkomplet. ${ }^{1}$ Pengetahuan yang baik tentang gambaran klinis dan pemeriksaan penunjang PK sangat diperlukan untuk dapat menegakkan diagnosis PK secara dini. ${ }^{13,14}$ Sejauh ini belum ada publikasi penelitian tentang PK di Indonesia.

\section{Metode}

Penelitian deskriptif potong lintang dilakukan pada saat diagnosis PK ditegakkan. Data diperoleh dari rekam medis pasien berusia 0-18 tahun dengan diagnosis PK di Rumah Sakit Umum Pusat Nasional Cipto Mangunkusumo (RSCM), RS Premier Bintaro (RSPB), dan RS Omni Alam Sutera Tangerang, selama periode 1 Agustus 2011 hingga 31 Juli 2012. Sampel 
diambil secara total sampling.

- Fase PK: akut, apabila perjalanan penyakit $<10$ hari pertama; subakut, apabila perjalanan penyakit hari ke10-25; konvalesens, apabila perjalanan penyakit $>$ hari 25 hingga 8 minggu dari awitan.

- Aneurisma arteri koroner: untuk right coronay artery (RCA) proksimal, left main coronary artery (LMCA) proksimal maupun left anterior descending (LAD) proksimal jika diameter internal $\geq 2,5 \mathrm{SD}$ $z$-score; atau diameter internal $\geq 1,5$ kali diameter segmen sekitarnya.

- Ukuran aneurisma: kecil, apabila diameter internal berukuran $<5 \mathrm{~mm}$; sedang, apabila diameter internal berukuran 5-8 $\mathrm{mm}$; raksasa, apabila diameter internal berukuran $>8 \mathrm{~mm}$.

- Diagnosis: dini, apabila ditegakkan dalam 10 hari pertama perjalanan penyakit; terlambat, bila ditegakkan pada $>10$ hari sejak awitan demam.

- Hipoalbuminemia ditentukan berdasarkan nilai rujukan pada masing-masing laboratorium, untuk RS Omni Alam Sutera Tangerang: disebut hipoalbuminemia bila $<3,0 \mathrm{~g} / \mathrm{dL}$ pada usia $<1$ tahun dan $<3,8 \mathrm{~g} / \mathrm{dL}$ pada usia $>1$ tahun. Pemeriksaan albumin serum tersebut menggunakan alat kimia analyzer ABX Pentra-400 dengan reagen brom cressol green.

- Gambaran infiltrat pada foto toraks: ditemukannya infiltrat pada salah satu bagian dari lapang paru, baik perihiler maupun parakardial bilateral atau unilateral.

- Respons terhadap IGIV: hasil baik, apabila demam turun dalam waktu $<48$ jam pasca-pemberian IGIV; gagal respons, apabila demam tidak turun dalam waktu $\geq 48$ jam pasca-pemberian IGIV pertama atau terjadinya rekurensi demam dan tanda inflamasi setelah mengalami perbaikan sebelumnya.

Data diolah dengan menggunakan program SPSS versi 17.0. Penelitian ini telah mendapatkan persetujuan kaji etik dari Komite Etik Penelitian FKUI-RSCM.

\section{Hasil}

Selama kurun waktu antara 1 Agustus 2011 hingga 31 Juli 2012 didapatkan 66 subjek yang sesuai dengan diagnosis PK. Enampuluh subjek didapatkan dari RS Omni Alam Sutera Tangerang, 2 subjek dari RSCM, dan 4 subjek dari RSPB. Subjek penelitian terbanyak didapatkan pada bulan September 2011 yaitu 12 subjek. Diagnosis PK komplet didapatkan 50 (76\%) dan PK inkomplet 16 (24\%) subjek. Diagnosis PK ditegakkan secara dini pada 46 (70\%) subjek, sedangkan pada 20 (30\%) lainnya terlambat didiagnosis. Subjek terbanyak didapatkan pada usia balita yaitu $77 \%$ dan sebagian besar berusia 1-5 tahun (59\%) dengan usia terbanyak 1-2 tahun. Median usia anak dengan diagnosis PK adalah 34 bulan dengan rentang 3 bulan-11 tahun 5 bulan. Anak lelaki didapatkan lebih banyak dibandingkan perempuan dengan perbandingan 2:1 (Tabel 1).

Semua pasien PK mengalami demam $\geq 5$ hari dengan median lama demam 8 hari (rentang 5-30 hari). Gejala klinis paling sering selain demam adalah perubahan bibir dan rongga mulut (seperti eritema, bibir pecah-pecah, lidah stroberi, dan eritema difus mukosa orofaring), injeksi konjungtiva tanpa eksudat, dan ruam polimorfik. Semua subjek mendapatkan imunoglobulin intravena (IGIV) dengan dosis $2 \mathrm{~g} /$ $\mathrm{kgBB}$ dan asam asetil salisilat dengan dosis 80-100 $\mathrm{mg} / \mathrm{kgBB} /$ hari. Delapanpuluh sembilan persen subjek memperlihatkan respon baik dengan 1 kali pemberian IGIV, sedangkan pada $11 \%$ subjek lainnya mengalami kegagalan respons terhadap pemberian IGIV awal (Tabel 2).

Selain gejala klinis klasik, beberapa subjek mengalami gejala keterlibatan organ lain, seperti artritis $6(9 \%)$ subjek, artralgia $3(4 \%)$, eritema dan

Tabel 1. Karakteristik subjek penelitian

\begin{tabular}{lcc}
\hline Karakteristik & $\begin{array}{c}\text { Jumlah } \\
(\mathrm{n}=66)\end{array}$ & $(\%)$ \\
\hline $\begin{array}{l}\text { Jenis kelamin } \\
\text { Lelaki }\end{array}$ & 45 & 68 \\
$\quad$ Perempuan & 21 & 32 \\
Kelompok usia (tahun) & & \\
$\quad<1$ & 12 & 18 \\
$\quad 1-5$ & 39 & 59 \\
$\quad>5$ & 15 & 23 \\
Etnis & & \\
$\quad$ Cina & 29 & 44 \\
$\quad$ Non-Cina & 37 & 56 \\
Riwayat keluarga dengan PK & & \\
$\quad$ Ya & 1 & 1 \\
$\quad$ Tidak & 65 & 99 \\
$\quad$
\end{tabular}


Tabel 2. Profil klinis penyakit Kawasaki

\begin{tabular}{lcc}
\hline Profil klinis & Jumlah $(\mathrm{n}=66)$ & $(\%)$ \\
\hline Manifestasi klinis & & \\
Injeksi konjungtiva tanpa eksudat & 58 & 88 \\
Perubahan pada bibir dan rongga mulut & 66 & 100 \\
Limfadenopati servikal unilateral & 35 & 53 \\
Ruam polimorfik & 59 & 89 \\
Perubahan pada ekstremitas & & \\
$\quad$ Fase akut: edema/eritema telapak tangan dan kaki & 44 & 67 \\
$\quad$ Fase subakut/konvalesens: deskuamasi periungual & 21 & 32 \\
Respons terhadap IGIV & & \\
Respons baik & 59 & 89 \\
Gagal respons & 7 & 11 \\
\hline
\end{tabular}

Tabel 3. Profil laboratoris penyakit Kawasaki

\begin{tabular}{lll}
\hline Hasil laboratorium & Jumlah & $\%$ \\
\hline Anemia & 37 & 56 \\
Leukositosis & 40 & 61 \\
Trombositosis & 38 & 58 \\
Peningkatan LED & 63 & 97 \\
Peningkatan CRP & 56 & 85 \\
Peningkatan SGOT dan/atau SGPT & 24 & 38 \\
Hipoalbuminemia & 45 & 70 \\
\hline
\end{tabular}

indurasi pada bekas parut BCG $3(4 \%) \mathrm{k}$, hepatomegali 3 (4\%), kelainan kulit berupa pustula multipel 1 (1\%), dan kejang 1 (1\%) subjek. Sebagian besar subjek menunjukkan peningkatan LED dan CRP, tetapi 10 (15\%) peningkatan LED tidak sejalan dengan CRP. Peningkatan LED tidak disertai oleh peningkatan CRP pada 9 subjek, sedangkan peningkatan CRP yang tidak disertai oleh peningkatan LED terjadi pada 1 subjek. Leukositosis didapatkan 61\% subjek dengan dominasi neutrofil segmen (Tabel 3). Leukopenia didapatkan 1

Tabel 4. Subjek dengan aneurisma arteri koroner

\begin{tabular}{|c|c|c|c|c|c|c|c|}
\hline \multirow[b]{2}{*}{ No } & \multicolumn{2}{|c|}{ Subjek } & \multirow[b]{2}{*}{ Diagnosis } & \multicolumn{4}{|c|}{ Aneurisma arteri koroner } \\
\hline & $\begin{array}{l}\text { Jenis } \\
\text { kelamin }\end{array}$ & $\begin{array}{l}\text { Usia (tahun/ } \\
\text { bulan) }\end{array}$ & & RCA & LMCA & LCX & LAD \\
\hline 1 & Perempuan & $6 / 2$ & dini & kecil & - & - & - \\
\hline 2 & Perempuan & $5 / 1$ & dini & - & kecil & - & - \\
\hline 3 & Laki-laki & $5 / 5$ & dini & - & kecil & - & - \\
\hline 4 & Laki-laki & $1 / 11$ & dini & - & kecil & - & - \\
\hline 5 & Laki-laki & $1 / 6$ & dini & - & - & kecil & - \\
\hline 6 & Perempuan & $0 / 4$ & dini & - & - & - & Kecil \\
\hline 7 & Laki-laki & $4 / 4$ & dini & - & - & - & Kecil \\
\hline 8 & Laki-laki & $0 / 3$ & dini & kecil & - & - & Kecil \\
\hline 9 & Laki-laki & $5 / 1$ & dini & kecil & - & - & Kecil \\
\hline 10 & Laki-laki & $4 / 9$ & dini & - & - & - & sedang \\
\hline 11 & Laki-laki & $3 / 9$ & terlambat & kecil & - & - & - \\
\hline 12 & Perempuan & $7 / 11$ & terlambat & kecil & - & - & - \\
\hline 13 & Perempuan & $6 / 6$ & terlambat & kecil & - & - & - \\
\hline 14 & Laki-laki & $1 / 0$ & terlambat & - & kecil & - & - \\
\hline 15 & Laki-laki & $0 / 5$ & terlambat & kecil & kecil & - & - \\
\hline 16 & Laki-laki & $4 / 0$ & terlambat & - & kecil & - & Kecil \\
\hline 17 & Laki-laki & $2 / 10$ & terlambat & kecil & kecil & - & Kecil \\
\hline 18 & Laki-laki & $1 / 2$ & terlambat & kecil & kecil & - & kecil \\
\hline 19 & Laki-laki & $3 / 11$ & terlambat & raksasa & kecil & - & Kecil \\
\hline 20 & Perempuan & $0 / 10$ & terlambat & sedang & kecil & - & sedang \\
\hline \multicolumn{3}{|c|}{ Jumlah } & & 11 & 10 & 1 & 10 \\
\hline
\end{tabular}


subjek. Leukosituria didapatkan 11 (17\%) subjek.

Anemia, leukositosis, trombositosis, peningkatan LED, CRP, SGOT dan/atau SGPT, serta hipoalbuminemia paling banyak didapatkan pada fase akut. Apabila dilihat dari lamanya demam, 36 dari 38 subjek (95\%) trombositosis terjadi di atas hari ke-7 demam. Rerata hemoglobin (Hb) 10,9 $\pm 1,06 \mathrm{~g} / \mathrm{dL}$, leukosit $15.129 \pm 5.525 / \mu \mathrm{L}$, dan LED 75,35 $\pm 34,79 \mathrm{~mm} / \mathrm{jam}$. Median trombosit 434.000 (152.000-1.196.000) / $\mu \mathrm{L}$, CRP 58,0 (0,1-450) mg/L, SGOT 29 (12-382) $\mu / \mathrm{L}$, SGPT 29 (6-634), dan albumin 3,5 (2,3-4,5) g/dL.

Kelainan foto toraks tersering yang ditemukan adalah adanya gambaran infiltrat pada 47 (71\%) subjek. Kardiomegali didapatkan satu subjek dan satu subjek yang menunjukkan gambaran abses paru pada foto toraks. Gambaran kelainan yang didapatkan pada EKG adalah sinus takikardia 29 (44\%) subjek, sedangkan kelainan lain tidak ditemukan.

Duapuluh (30\%) subjek menunjukkan aneurisma arteri koroner pada ekokardiografi yang dilakukan saat awal diagnosis. Efusi perikardium didapatkan 18 (27\%), perivascular brightness 12 (18\%), dan regurgitasi katup mitral 5 (8\%) subjek. Tidak didapatkan trombosis, stenosis koroner, maupun infark miokard. Aneurisma arteri koroner didapatkan 10/46 (22\%) subjek yang didiagnosis dini, sedangkan didiagnosis terlambat 10/20 (50\%) subjek.

Pada diagnosis dini tujuh subjek menunjukkan aneurisma tunggal dengan ukuran kecil, dua aneurisma multipel dengan ukuran kecil, dan satu aneurisma tunggal dengan ukuran sedang. Subjek dengan diagnosis terlambat menunjukkan aneurisma tunggal dengan ukuran kecil empat subjek, sedangkan 6 lainnya menunjukkan aneurisma multipel dengan satu menunjukkan aneurisma sedang dan satu subjek aneurisma raksasa (Tabel 4).

\section{Pembahasan}

Pada penelitian kami, subjek terbanyak didapatkan pada bulan September 2011 yaitu 12 subjek. Pada bulan tersebut sebagian besar wilayah Indonesia termasuk Jakarta dan sekitarnya sedang memasuki awal musim hujan, tetapi hal tersebut belum menjadi data yang berarti karena tidak didapatkan pola yang jelas mengenai dominasi sebaran frekuensi PK pada musim tersebut. Selain itu, penelitian ini mengambil waktu 1 tahun sehingga sulit melihat apakah pada musim tersebut kasus PK memang sering ditemukan. Penelitian di Amerika Serikat disebutkan bahwa PK lebih sering ditemukan selama musim dingin dan awal musim semi. ${ }^{16}$ Demikian pula penelitian oleh Kayiran $\mathrm{dkk}^{17}$ di Istanbul Turki yang mendapatkan bahwa PK lebih sering ditemukan pada musim dingin. Berbeda halnya dengan penelitian oleh Huang $\mathrm{dkk}^{18}$ di Taiwan yang menemukan bahwa PK lebih sering ditemukan pada musim panas. Adanya dominasi kejadian PK pada bulan atau musim tertentu di beberapa negara menimbulkan dugaan bahwa PK dicetuskan oleh faktor lingkungan.

Diagnosis PK komplet didapatkan 76\% subjek, sedangkan PK inkomplet 24\%. Sebagian besar subjek PK inkomplet didapatkan pada usia $<3$ tahun $(10 / 16$ subjek). Beberapa literatur mengungkapkan bahwa PK inkomplet lebih sering ditemukan pada bayi usia muda. ${ }^{1}$ Pada penelitian kami, angka kejadian PK anak lelaki lebih tinggi dibandingkan perempuan dengan perbandingan 2:1. Hal tersebut sesuai dengan penelitian lain yang mendapatkan angka kejadian PK pada anak lelaki lebih tinggi dibandingkan perempuan. ${ }^{17-21}$ Penyakit Kawasaki umumnya ditemukan pada anak balita dan jarang ditemukan pada usia di bawah 3 bulan atau di atas 8 tahun. 3 . Usia balita pada penelitian kami 77\% subjek dengan usia tersering 1-2 tahun. Hal serupa juga didapatkan pada penelitian Kayiran dkk, ${ }^{17}$ Huang dkk, ${ }^{18}$ dan Moradinejad dkk ${ }^{19}$ di Iran yang mendapatkan proporsi usia balita 85,7\%, 90\%, dan $92 \%$.

Angka rekurensi PK di Jepang 3\%, adanya riwayat keluarga terkena PK berkisar 1\%, sedangkan risiko kejadian pada saudara kembar PK berkisar 13\%.,10 Belum ada bukti bahwa penyakit ini menular. ${ }^{4,5,22} \mathrm{Pada}$ penelitian kami, riwayat PK pada keluarga didapati pada 1 subjek (1\%), sedangkan angka rekurensi belum dapat ditentukan karena untuk melihat rekurensi dibutuhkan pemantauan lebih lanjut. Penyakit ini dapat ditemukan di seluruh penjuru dunia dengan kasus tersering dijumpai pada orang Asia terutama Jepang, Cina, dan Korea. ${ }^{23}$ Angka kejadian yang tinggi pada kelompok Asia menunjukkan adanya predisposisi genetik, meskipun belum diketahui secara pasti. ${ }^{17}$ Pada penelitian kami, 44\% subjek PK merupakan warga keturunan Cina. Dominasi PK pada warga keturunan Cina tidak tampak karena proporsi warga keturunan Cina di Indonesia berdasarkan sensus penduduk tahun 2010 adalah 1,2\%. ${ }^{24}$ Apabila dibandingkan dengan populasi penduduk Indonesia secara keseluruhan, 
maka proporsi PK warga keturunan Cina di Indonesia mungkin akan lebih banyak dibandingkan warga non-Cina.

Seluruh subjek penelitian kami mengalami demam. Gambaran klinis tersering yang didapatkan adalah perubahan kavum oral dan bibir pada semua subjek, ruam polimorfik pada $89 \%$ subjek, dan injeksi konjungtiva tanpa eksudat pada $88 \%$ subjek. Gambaran klinis paling jarang adalah limfadenopati servikal unilateral yang didapatkan pada 53\% subjek. Limfadenopati servikal unilateral muncul dalam frekuensi yang bervariasi antara 50\%-75\% subjek, sedangkan gejala lain mencapai $90 \% .{ }^{25}$ Hasil serupa didapatkan pada penelitian lain ${ }^{17-21,26}$ Fan $\mathrm{dkk}^{27}$ mendapatkan bahwa limfadenopati servikal unilateral sering muncul pada anak usia sekolah sebagai manifestasi utama PK.

Selain gejala klinis klasik, gejala klinis lainnya dapat dijumpai pada PK. Artritis atau artralgia dapat muncul pada minggu pertama perjalanan penyakit dan mengenai banyak sendi, baik sendi kecil maupun besar. ${ }^{1}$ Pada penelitian kami, artritis didapatkan 6 (9\%) subjek dan artralgia masing-masing 3 (4\%) subjek, tetapi data rekam medis tidak tertera area yang terkena maupun durasinya. Moradinejad $\mathrm{dkk}^{19} \mathrm{di}$ Iran menemukan artritis dan artralgia berturut-turut 15\% dan 22\%. Eritema dan indurasi pada bekas parut BCG sering didapatkan pada pasien PK di Jepang, tetapi pada penelitian ini hal tersebut didapatkan pada 3 subjek (4\%). Hasil serupa dilaporkan oleh Kayiran dkk, ${ }^{17}$ Consul dkk, ${ }^{20}$ dan Moradinejad dkk ${ }^{19}$ yang mendapatkan eritema dan indurasi pada bekas parut BCG pada 2,8\%, 4,5\%, dan 8,8\% kasus.

Tata laksana utama PK adalah pemberian IGIV. Mekanisme kerja IGIV pada PK masih belum jelas, tetapi IGIV telah terbukti dapat menurunkan kejadian kelainan arteri koroner. ${ }^{28}$ Rekomendasi AHA untuk pengobatan PK adalah pemberian IGIV $2 \mathrm{~g} / \mathrm{kgBB}$ dosis tunggal dan asam asetil salisilat $80-100 \mathrm{mg} / \mathrm{kgBB}$. Pengobatan tersebut paling efektif apabila diberikan dalam waktu 10 hari pertama. ${ }^{1}$ Semua pasien pada penelitian kami mendapatkan IGIV dan asam asetil salisilat sesuai dengan rekomendasi AHA. Didapatkan $89 \%$ subjek menunjukkan respons baik pasca-pemberian IGIV, sedangkan 7 (11\%) subjek mengalami kegagalan respons. Imunoglobulin intravena kedua dengan dosis yang sama diberikan pada 7 subjek tersebut dan demam turun dalam waktu $<48$ jam.

Sampai saat ini, belum ada pemeriksaan labo- ratorium diagnostik untuk $\mathrm{PK}$, tetapi temuan laboratorium tertentu dapat membantu dalam menegakkan diagnosis. Anemia normositik normokrom dapat terjadi dalam 2 minggu pertama perjalanan penyakit. ${ }^{1,8}$ Anemia terjadi pada fase akut dan subakut, kemudian $\mathrm{Hb}$ dapat meningkat dengan sendirinya pada fase konvalesens. Anemia pada fase akut dapat disebabkan oleh penurunan produksi sel darah merah akibat proses inflamasi akut sehingga anemia akan membaik tanpa pengobatan khusus pada fase konvalensens. ${ }^{29}$ Kami mendapatkan 56\% subjek anemia, sebagian besar terjadi pada fase akut. Penelitian ini tidak mendapatkan data $\mathrm{Hb}$ pada fase konvalesens. Hasil yang hampir serupa didapatkan oleh Kayiran $\mathrm{dkk}^{17}$ dari Istanbul Turki terhadap 35 anak dengan PK yang mendapatkan anemia pada $40 \%$ subjek.

Hitung leukosit pada umumnya normal sampai tinggi dengan predominan neutrofil dan bentuk imatur. ${ }^{8}$ Sekitar $50 \%$ pasien mempunyai hitung leukosit $>15.000 / \mu \mathrm{L}$, leukopeni jarang ditemukan. ${ }^{1}$ Kami mendapatkan $61 \%$ subjek leukositosis dengan dominasi neutrofil segmen, sedangkan satu subjek leukopenia. Sebagian besar leukositosis didapatkan pada fase akut. Trombositosis merupakan gambaran laboratorium yang khas pada fase subakut. Trombositosis didapatkan pada 38 subjek (58\%). Apabila dilihat dari lamanya demam, 95\% subjek yang mengalami trombositosis terjadi setelah hari ke-7 demam. Hal tersebut sesuai dengan literatur yang menyebutkan bahwa trombositosis mulai terjadi pada minggu kedua dan mencapai puncaknya pada minggu ketiga, kemudian kembali normal secara bertahap pada 4-8 minggu setelah awitan penyakit. Trombositosis jarang terjadi pada minggu pertama perjalanan penyakit. ${ }^{1,8}$

Peningkatan LED, CRP, dan reaktan fase akut lainnya hampir selalu ada pada fase akut dan kembali normal setelah 6-10 minggu sejak awitan penyakit. ${ }^{1,8}$ Laju endap darah dan CRP merupakan dua dari beberapa reaktan fase akut yang menggambarkan respons fase akut terhadap proses inflamasi. Kadar LED dalam plasma dipengaruhi oleh banyak faktor, seperti ukuran dan bentuk sel darah merah, fibrinogen, komposisi plasma, status cairan, dan obat, sedangkan CRP tidak dipengaruhi oleh hal-hal tersebut. ${ }^{30}$ Pada penelitian kami, peningkatan LED dan CRP sebagian besar terjadi pada fase akut. Peningkatan LED terjadi pada 97\% subjek, sedangkan peningkatan CRP 85\% subjek. Pada 10 (15\%) subjek peningkatan LED tidak sejalan dengan CRP. Hal tersebut mungkin disebabkan oleh 
peningkatan CRP terjadi dalam waktu yang lebih cepat pada fase akut, sedangkan peningkatan LED memerlukan waktu yang lebih lama. Sebaliknya LED mungkin masih meningkat saat fase subakut atau konvalesens, sementara CRP sudah mencapai nilai normal. Hal serupa diungkapkan oleh Anderson dkk ${ }^{31}$ yang mendapatkan ketidaksesuaian peningkatan LED dengan CRP pada $44 \%$ subjek. Penelitian tersebut menganjurkan agar kedua pemeriksaan tersebut dilakukan, tidak hanya salah satunya saja.

Kadar transaminase serum meningkat ringan sampai sedang pada kurang dari $40 \%$ kasus dan bersifat transien. ${ }^{1}$ Kami mendapatkan peningkatan SGOT dan/atau SGPT pada 38\% subjek. Peningkatan kadar transaminase serum dilaporkan berhubungan dengan kejadian resistensi IGIV. ${ }^{32}$ Hipoalbuminemia dapat terjadi dan berhubungan dengan keparahan penyakit. ${ }^{1}$ Kami mendapatkan angka hipoalbuminemia yang cukup tinggi pada $70 \%$ subjek, sedangkan Moradinejad $\mathrm{dkk}^{19}$ mendapatkan hipoalbuminemia pada $15 \%$ kasus. Sebagian besar subjek penelitian kami menunjukkan hipoalbuminemia ringan dengan median kadar albumin serum 3,5 (2,3-4,5) g/dL. Kejadian hipoalbuminemia yang tinggi mungkin dipengaruhi oleh cukup tingginya nilai rujukan kadar albumin serum pada batasan operasional sebagian besar subjek, yaitu $<3 \mathrm{~g} / \mathrm{dL}$ pada usia $<1$ tahun dan $<3,8 \mathrm{~g} / \mathrm{dL}$ pada usia $>1$ tahun. Mekanisme hipoalbuminemia pada PK belum diketahui dengan jelas, tetapi diduga merupakan akibat multifaktor. Proses inflamasi mengakibatkan protein fase akut seperti CRP diproduksi oleh hati sehingga sebagai kompensasinya produksi protein lain seperti albumin mengalami penurunan. Selama fase akut PK, albumin dapat keluar dari intravaskular ke ruang interstitial akibat peningkatan permeabilitas kapiler. $^{32}$

Pada pemeriksaan urinalisis dapat ditemukan piuria steril ringan sampai sedang yang bersifat intermiten. Piuria steril dapat terjadi pada $33 \%$ kasus, meskipun urin suprapubik umumnya tidak menunjukkan piuria, sehingga sering diduga sebagai uretritis. ${ }^{1}$ Kami mendapatkan leukosituria pada 11 (17\%) subjek, kultur urin yang dilakukan pada satu subjek menunjukkan hasil steril dan pemeriksaan urin ulangan yang dilakukan pada 3 subjek menunjukkan hasil normal.

Foto toraks dan EKG dapat menujukkan gambaran yang tidak spesifik. Pada penelitian kami, gambaran infiltrat pada foto toraks didapatkan $71 \%$ subjek. Keterlibatan paru pada PK dapat berupa infiltrat mikronodular yang asimptomatis hingga nodul paru yang disertai gejala peradangan. Infiltrat dan nodul pada paru mungkin disebabkan oleh respons tubuh terhadap agen etiologik PK dan dapat membaik dengan sendirinya seiring dengan proses perbaikan penyakit. ${ }^{33}$ Kami tidak menemukan gejala respiratorik, sehingga infiltrat pada foto toraks merupakan tanda yang asimptomatis. Temuan tersebut berbeda dengan laporan lain yang menyatakan bahwa keterlibatan organ paru pada PK jarang ditemukan. ${ }^{34-36}$ Pada penelitian kami, kemungkinan penyakit lain yang dapat memberikan gambaran infiltrat pada foto toraks tidak dideskripsikan pada sebagian besar kasus. Kelainan EKG yang ditemukan adalah sinus takikardia pada 44\% subjek, sedangkan kelainan lain tidak ditemukan. Sinus takikardia memang dapat ditemukan pada PK, tetapi bukan merupakan gambaran yang spesifik pada PK karena dapat disebabkan oleh penyebab lain, seperti demam, gelisah, dan nyeri. Kami tidak dapat mengonfirmasi hal tersebut karena data diambil secara retrospektif.

Ekokardiografi harus dilakukan pada semua pasien dengan diagnosis PK atau dugaan PK untuk mendeteksi kelainan arteri koroner dan gangguan fungsi jantung yang lain. Ekokardiografi pada setiap fase PK harus memperhatikan kelainan arteri koroner, disfungsi katup, fungsi miokardium, dan keterlibatan perikardium. ${ }^{37}$ Penurunan fungsi ventrikel kiri dapat ditemukan pada fase akut sebagai pertanda terjadinya miokarditis. Regurgitasi katup trikuspid, mitral, dan aorta dapat dijumpai pada 50\% anak pada fase akut, diduga akibat miokarditis, infark miokard atau oklusi arteri koroner. Dapat juga dijumpai efusi perikardium. Pada penelitian kami, data ekokardiografi yang diambil adalah ekokardiografi pada saat diagnosis PK ditegakkan. Baer $\mathrm{dkk}^{38}$ mengungkapkan bahwa lesi arteri koroner sering didapatkan pada ekokardiografi awal pasien PK dengan angka kejadian 44\%. Penelitian Consul $\mathrm{dkk}^{20}$ di India, didapatkan angka kejadian aneurisma arteri koroner pada ekokardiografi awal sebesar 36\%. Kami mendapatkan aneurisma arteri koroner pada $20(30 \%)$ subjek. Aneurisma arteri koroner didapatkan pada 10 dari 46 (22\%) subjek yang didiagnosis dini, sedangkan pada subjek yang didiagnosis terlambat 10 dari 20 (50\%) subjek. Apabila dilihat dari waktu diagnosis, subjek dengan diagnosis dini lebih banyak mengalami aneurisma tunggal dengan ukuran kecil, yaitu pada 7 dari 10 subjek (70\%) dibandingkan 4 dari 10 subjek (40\%) pada subjek dengan diagnosis terlambat. Sebaliknya, 
aneurisma multipel, aneurisma sedang, dan raksasa lebih banyak ditemukan pada subjek dengan diagnosis terlambat. Hal tersebut menunjukkan diagnosis dan tata laksana dini sangat penting untuk meminimalkan kelainan arteri koroner. Kami tidak mendapatkan trombosis, stenosis koroner, maupun infark miokard.

Keterbatasan penelitian adalah pengumpulan data dilakukan secara retrospektif dari rekam medis, sehingga data yang diperoleh hanya terbatas pada apa yang tercantum dalam rekam medis. Hal tersebut menimbulkan beberapa kekurangan, seperti data yang diperoleh kurang lengkap, dan terdapat beberapa data laboratorium serta pemeriksaan penunjang yang tidak ditemukan. Meskipun demikian, penelitian ini merupakan penelitian awal PK pada populasi anak di Indonesia yang dapat memberikan gambaran bagi para tenaga medis untuk menduga atau mendiagnosis PK agar pengobatan tidak terlambat.

\section{Kesimpulan}

Gambaran klinis paling sering selain demam adalah perubahan pada bibir dan rongga mulut, ruam polimorfik, dan injeksi konjungtiva tanpa eksudat, sedangkan limfadenopati servikal unilateral jarang ditemukan. Pemeriksaan LED dan CRP sebaiknya dilakukan bersamaan untuk mendukung diagnosis. Hipoalbuminemia dan gambaran infiltrat pada foto toraks dapat dipertimbangkan sebagai alat bantu diagnosis $\mathrm{PK}$, tetapi masih membutuhkan penelitian lebih lanjut untuk membuktikannya.

\section{Daftar pustaka}

1. Newburger JW, Takahashi M, Gerber MA. Diagnosis, treatment, and long-term management of Kawasaki disease: a statement for health professionals from the committee on rheumatic fever, endocarditis, and Kawasaki disease, council on cardiovascular disease in the young, American heart association. Pediatrics 2004;114:1708-33.

2. Freeman AF, Shulman ST. Kawasaki disease: summary of the American heart association guidelines. Am Fam Physician 2006;74:1141-8.

3. Kim DS. Kawasaki disease. Yonsei Med J 2006;47:75972.

4. Machonochie IK. Kawasaki disease. Arch Dis Child Ed
Pract. 2004;89:3-8.

5. Advani N. Mengenal penyakit Kawasaki. Jakarta: Departemen Ilmu Kesehatan Anak FKUI; 2004.h.115.

6. Fimbers AM, Shulman ST. Kawasaki disease. Pediatr Rev 2008;29:308-16.

7. Chakrabartty S, Pramanik S, Thapa R. Difficulties in the diagnosis of Kawasaki disease. Indian Pediatr 2006;43:728-31.

8. Rowley AH, Shulman ST. Kawasaki disease. Dalam: Kliegman RM, Behrman RE, Jenson HB, Stanford BF, penyunting. Nelson Textbook of Pediatrics. Edisi ke-18. Philadelphia: Saunders; 2007.h.1036-42.

9. Burns JC, Kushner HI, Bastian JF. Kawasaki disease: a brief history. Pediatrics. 2000;106:27-39.

10. Nakamura Y, Yashiro M, Uehara R. Epidemiologic features of Kawasaki disease in Japan: results of the 20072008 nationwide survey. J Epidemiol 2010;20:302-7.

11. Advani N, Lukito B, Sastroasmoro S. Epidemiology of Kawasaki disease: data in Indonesia. Proceedings of the $9^{\text {th }}$ International Kawasaki Disease Symposium. Taipei, Taiwan. April 2008.

12. Setiabudiawan B, Ghrahani R, Sapartini G. Penyakit Kawasaki atipikal. MKB 2011;43:146-52.

13. Advani N. Berbagai kesulitan dalam menegakkan diagnosis penyakit Kawasaki. Dalam: Pediatric Cardiology Update 2012. Jakarta: Ikatan Dokter Anak Indonesia; 2012.h.104.

14. Advani N. Penyakit Kawasaki dan dampaknya pada penderita dan komunitas. Sari Pediatri 2007;8:127-32.

15. Gersony WM. The adult after Kawasaki disease. J Am Coll Cardiol. 2009;21:1921-3.

16. Holman RC, Curns AT, Belay ED. Kawasaki syndrome hospitalizations in the United States, 1997-2000. Pediatrics 2003;112:495-501.

17. Kayiran SM, Dindar A, Gurakan B. An evaluation of children with Kawasaki disease in Istanbul: a retrospective follow-up study. Clinics 2010;65:1261-5.

18. Huang WC, Huang LM, Chang IS. Epidemiologic features of Kawasaki disease in Taiwan, 2003-2006. Pediatrics 2009;123:401-5.

19. Moradinejad MH, Kiani A. Kawasaki disease in 159 Iranian children. Iran J Ped 2007;17:241-6.

20. Consul M, Mishra S, Taneja A. Spectrum of Kawasaki disease. Indian J Pediatr 2011;78:488-90.

21. Davaalkham D, Nakamura Y, Baigalmaa D. Kawasaki disease in Mongolia: results from 2 nationwide retrospective surveys, 1996-2008. J Epidemiol 2001;21: 293-8. 
22. Baker AL, Newburger JW. Kawasaki disease. Circulation 2008;118:110-2.

23. Rowley AH, Shulman ST. Pathogenesis and management of Kawasaki disease. Expert Rev Anti Infect Ther 2010;2:197-203.

24. Na'im A, Syaputra H. Dalam: Sumarwanto, Iriantomo $\mathrm{T}$, penyunting. Kewarganegaraan, suku bangsa, agama, dan bahasa sehari-hari penduduk Indonesia. Hasil sensus penduduk 2010. Jakarta: Badan Pusat Statistik; 2010.h.8-24.

25. Singh S, Kawasaki T. Kawasaki disease-an Indian perspective. Indian Pediatr 2009;46:563-71.

26. Marquez J, Gedalia O, Candia L. Kawasaki disease: clinical spectrum of 88 patients in a high-prevalence African-American population. J Natl Med Assoc 2008;100:28-32.

27. Fan PC, Chiu CH, Yen MH. School-aged children with Kawasaki disease: high incidence of cervical lymphadenopathy and coronary artery involvement. J Pediatr Child Health 2003;39:55-7.

28. Durongpisitkul K, Gururaj VJ, Park JM. The prevention of coronary artery aneurysm in Kawasaki disease: a metaanalysis on the efficacy of aspirin and immunoglobulin treatment. Pediatrics. 1995;96:1057-61.

29. Tremoulet AH, Jain S, Chandrasekar D. Evolution of laboratory values in patients with Kawasaki disease. Pediatr Infect Dis J 2011;30:1022-6.

30. $\mathrm{Ng} \mathrm{T}$. Erythrocyte sedimentation rate, plasma viscosity and C-reactive protein in clinical practice. Br J Hosp Med 1998;58:521-3.

31. Anderson MS, Burns J, Treadwell TA. Erythrocyte sedimentation rate and C-reactive protein discrepancy and high prevalence of coronary artery abnormalities in Kawasaki disease. Pediatr Infect Dis J 2001;20:698-702.

32. Eladawy M, Dominguez SR, Anderson MS. Abnormal liver panel in acute Kawasaki disease. Pediatr Infect Dis J 2011;30:141-4.

33. Freeman AF, Crawford SE, Finn LS. Inflamatory pulmonary nodules in Kawasaki disease. Pediatr Pulmonol 2003;36:102-6.

34. Manganelli P, Fietta P, Carroti M. Respiratory system involvement in systemic vasculitidies. Clin Exp Rheumatol 2006;24:48-59.

35. Moredero P, Gomez F, Molina FR. Radiologic findings in the lungs of patients with Kawasaki disease. Radiologia. 2006;48:14-8.

36. Umezawa T, Saji T, Matsua N, dkk. Chest X-ray findings in the acute phase of Kawasaki disease. Pediatr Radiol. 1989;20:48-51.

37. Kawasaki's disease. Dalam: Park MK, Troxler RG. Pediatric cardiology for practitioners. Edisi ke-5. St Louis: Mosby; 2008.h.453-64.

38. Baer AZ, Rubin LG, Shapiro CA. Prevalence of coronary artery lesions on the initial echocardiogram in Kawasaki syndrome. Arch Pediatr Adolesc Med 2006;160:68690 . 